\title{
SPANISH SUSTAINABLE DEVELOPMENT THROUGH ADMINISTRATIVE LAW
}

\author{
María Lidón LaRa ORTiz ${ }^{1}$ \\ Universitat Jaume I (Spain)
}

\begin{abstract}
This paper contains an assessment of the accomplishment of the Sustainable Development Goals in Spain through administrative law, pointing out the main regulations, and the most outstanding actions taken through public programmes and plans proficient to have a great impact on each and every one of the 17 SDGs. The research has been carried out through an initial theoretical study that involves a review of the main literature on the SDGs, Spanish law, and the study of case law related to some SDGs. After exposing the main theoretical questions of each SDG, a survey was carried out to quantitatively measure the degree of compliance with the SDGs through administrative regulation, and to analyse the possibilities for further regulatory development. The results are different in relation to each SDG, as the study shows. However, it can be anticipated that the average degree of compliance with the set of SDGs is medium-high, but more measures can be promoted to reach full compliance.

KEY WORDS: sustainable development, administrative law, regions, public administrations.
\end{abstract}

JEL CODES: K23, I38, I23, I25.

DOI: http://dx.doi.org/10.15181/rfds.v34i2.2248

\section{Introduction}

The research shows the degree of accomplishment of the Sustainable Development Goals (SDGs) through Spanish administrative law. The main objective is to offer a complete and detailed view of the current regulation for compliance with the milestones of the SDGs in Spain. The problem we pose is the convenience of taking further administrative measures in some way, so that by 2030 the SDGs will have been fully achieved. For this, it is necessary to evaluate the degree of compliance and the possibilities for future development. Considering this, the relevance of the study is determined by its usefulness in getting to know the current situation, and the weaknesses observed in relation to the SDGs in Spain, in order to propose improvements that can be implemented in the decade 2021 to 2030. The investigation starts from a detailed qualitative analysis of each SDG from the point of view of theoretical administrative law and by case law, including the main regulations, plans and administrative programmes carried out in Spain to reach each SDG. The qualitative aspect is obtained from specific seminars regarding each SDG, in which the control group has an active role through collaborative learning techniques (Lucero MM, 2003: 5), which is intended to encourage autonomous learning about this issue (Moreno, Martínez, 2006; Peña Calvo, 1998: 621-630; Coll, Martín, 2006). The quantitative aspect is the result of a critical analysis carried out with feedback from surveys answered by the control group which was formed from those who participated in the theoretical seminars and consisted of 52 people. The quantitative results for each SDG refer to: 1) Whether in Spanish administrative law there are sufficient and adequate regulations to achieve full compliance with each SDG; 2) If each SDG is fully accomplished in Spain through such regulations; and 3) To what extent can more measures be taken

María Lidón Lara Ortiz - dr. assistant professor

Scientific field: administrative law, Public Law Department, Jaume I University (Universitat Jaume I), Spain

E-mail: mlara@uji.es

Tel. +34964728677 
through administrative regulation to fulfil compliance with each SDG. Regarding these questions, the control group was asked to indicate from 1 to 5 , where 1 is the lowest degree and 5 is the highest degree, about the existence of regulation, compliance or possibilities for future normative development.

Given the multidisciplinary and varied nature of each SDG, it is not possible to offer a common theoretical background. For this reason, it has been considered more appropriate to make a brief individualised reference to the theoretical basis of each SDG in a specific and separate way, as follows.

\section{Accomplishment of SDG 1. End of poverty}

In Spain, the National Institute of Statistics set the poverty threshold for 2019 at 9,009.2 euros per year for one-person households, and 18,918.3 euros for households with two adults and two children (INE, 2020). There is also an Operational Plan for the development of a national strategy for the prevention and fight against poverty and social exclusion (2019), and other complementary plans implemented by the Ministry of Health, Consumption and Social Welfare, and refer to the minimum vital income, the minimum inter-professional salary, and the multiple effects public income indicator used as a reference for public aid and other benefits. In this regard, in Spain there is a Comprehensive National Strategy for the Homeless 2015-2020, and the 24/2015 Act of July 29 on urgent measures to face the emergency in the area of housing and energy poverty, which forbids the possibility of cutting off basic supplies to vulnerable families at risk of residential exclusion. Considering the former measures, $88.45 \%$ of the surveyed people selected degrees 3 and 4 regarding the question of the existence of regulation in Spain in relation to SDG 1, although it does not reach its full development. Figure 2 shows that $25.49 \%$ considered that compliance is low, placing it at between 1 and 2, and 74.51\% placed the degree of compliance in a medium-high position (degrees 3 and 4). Figure 3 represents the possibilities offered by Spanish administrative law to implement more measures aimed at achieving full compliance with this SDG, considering that $49.02 \%$ of those surveyed said that this SDG has possibilities for further development to a medium-high degree, between degrees 4 and 5 .

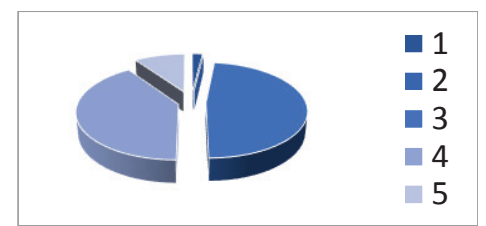

Figure 1. SDG 1 regulation

Source: the author, 2021.

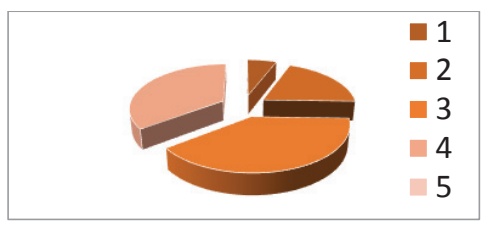

Figure 2. SDG 1 accomplishment

Source: the author, 2021.

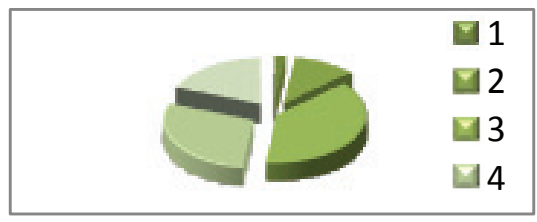

Figure 3. SDG 1 development

Source: the author, 2021.

\section{Accomplishment of SDG 2. Zero hunger}

This SDG has a strong connection with SDG 1, and the measures aimed at ending poverty can also be applied to SDG 2. Others can also be added, especially those related to promoting production, sustainable agriculture, and making public investment in infrastructure and technology with the purpose of favouring depressed rural areas (United Nations, 2020).

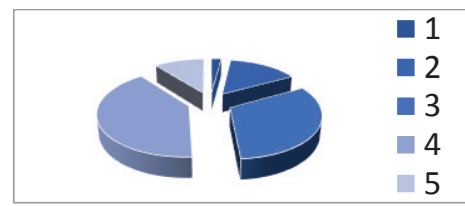

Figure 4. SDG 2 regulation

Source: the author, 2021.

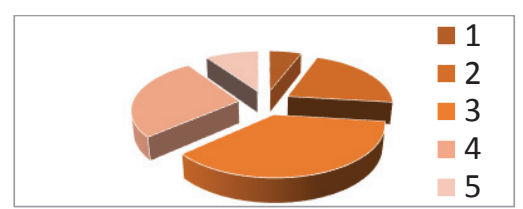

Figure 5. SDG 2 accomplishment

Source: the author, 2021.

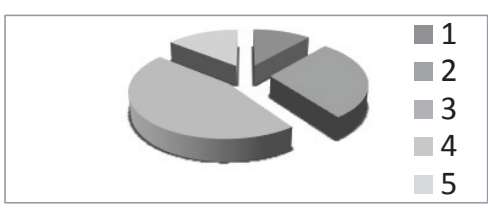

Figure 6. SDG 2 development

Source: the author, 2021. 
The research shows that this objective has a medium-high degree of regulation in Spain, since $72.34 \%$ of the surveyed people placed the degree of normative development at 3 or 4 (Figure 4), only $10.64 \%$ consider that there is a greater degree of normative development, and the other $17.02 \%$ understand that regulation is still insufficient, choosing grades 1 and 2. Figure 5 shows that $70 \%$ of the control group appreciate that it is a medium-high degree of accomplishment ( 3 and 4). The majority of the control group (89.36\%) placed the possibilities for future development between 3 and 5, while nobody grades it at 1, as shown in Figure 6.

\section{Accomplishment of SDG 3. Health and well-being}

The core of the material research was the extension of administrative organisation and the distribution of power in the National Health System, contained in the 14/1986 Act of April 25, in relation to the cohesion and quality of the National Health System 16/2003 Act of May 28, and with the General Public Health $33 / 2011$ Act of October 4. The research considered the health management of the Covid-19 pandemic and the regulation of the state of alarm approved to manage the health crisis during 2020. It was highlighted that there are other questions regarding this issue, such as the regulation of the guarantees and rational use of medicines and health products through the Royal Legislative Decree 1/2015 of July 24. Social welfare has many dimensions, admitting a much deeper study in all of them (Lázaro Guillamón et al., 2020), such as social housing policies, among others. The survey shows that regarding SGD3, the degree of normative development in favour of SDG 3 is medium-high, since $66.67 \%$ of the control group choose to indicate degrees 4 and 5 (Figure 7). Consequently, the degree of compliance is medium-high, as is shown in Figure 8, since $86.27 \%$ appreciate that the level of compliance scores between 3 and 5. It is still possible to improve it, as is shown in Figure 9, where $76.92 \%$ of the surveyed people chose degrees 3 to 5 to indicate further normative development possibilities.

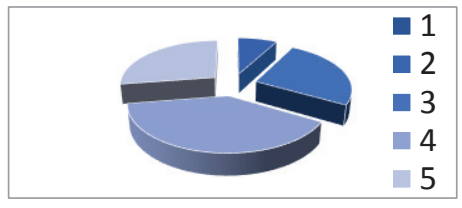

Figure 7. SDG 3 regulation

Source: the author, 2021.

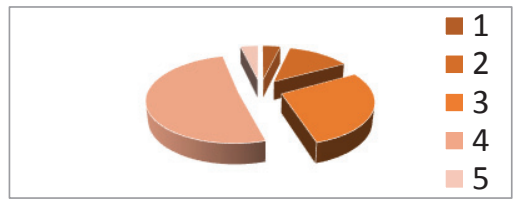

Figure 8. SDG 3 accomplishment

Source: the author, 2021.

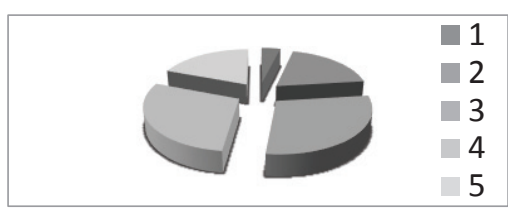

Figure 9. SDG 3 development

Source: the author, 2021.

\section{Accomplishment of SDG 4. Quality education}

The education system in Spain is organised with clear administrative powers, well-structured levels of education, and regulations on Fundamental Laws, such as 2/2006 of 3 May on Education, and Fundamental Law 8/2013 of December 9 for the improvement of educational quality, and basic guidelines for administrative procedure in the field of education.

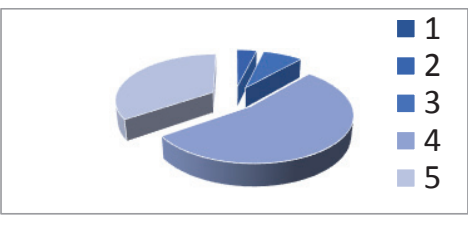

Figure 10. SDG 4 regulation

Source: the author, 2021.

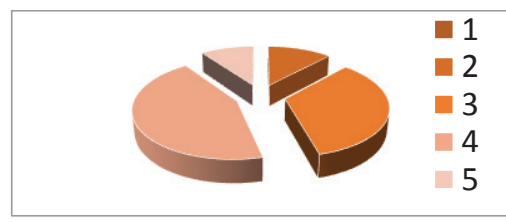

Figure 11. SDG 4 accomplishment Source: the author, 2021.

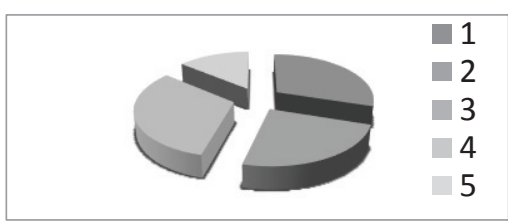

Figure 12. SDG 4 development

Source: the author, 2021. 
The results show that Spanish administrative regulations have contributed to achieve a high degree of compliance with this SDG. Current normative development is placed by $88.46 \%$ of the control group at between 4 and 5 (Figure 10), giving rise to a degree of compliance that $57.69 \%$ place between 4 and 5 (Figure 11). Consequently, as is shown in Figure 12, the measures that could still be incorporated are located in the moderate spectrum (degrees 2, 3 and 4), since according to $82.69 \%$ of the people surveyed, the possibility of adopting more measures is low, due to the quality of current regulations.

\section{Accomplishment of SDG 5. Gender equality}

This SDG should be considered an essential minimum in any field, but also in business it can become a competitive advantage (Brotó, Lapiedra, 2020, 110), which without doubt should be incorporated on regulations. The control group was informed about Directive 2006/54/EC on the application of the principle of equal opportunities and equal treatment between men and women in employment and occupation matters, and in Spain about Fundamental Law 3/2007 of March 22 for the effective equality of women and men that promote gender equality in a general sense. Regarding case law, there are interesting sentences that deal with the application of this SDG in the field of public administration, extending this principle to the civil service and employment relationship of staff in all public administration. This possibility covers a much larger area, since the Istanbul Convention recognises gender violence as a violation of human rights, being solid legal grounds for achieving this goal (Ventura Franch, 2016, 179-208). There is a strong opinion (73.08\%) that points out that this SDG has a medium-high normative development, as is shown in Figure 13, placing this issue in degrees 4 and 5. However, Figure 14 is very clear when it shows that the majority consider that the degree of full compliance with SDG 5 is still very far away, since $65.38 \%$ selected lower grades (from 1 to 3 degrees). Consistent with this last data, Figure 15 shows that $63.46 \%$ of the control group think that there is a high margin to implement more measures (Figure 15).

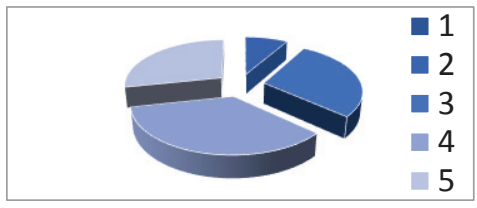

Figure 13. SDG 5 regulation

Source: the author, 2021.

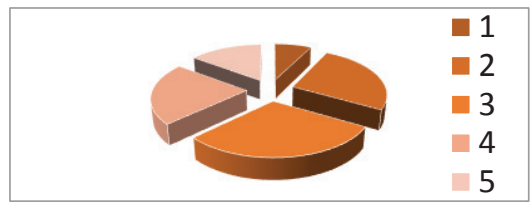

Figure 14. SDG 5 accomplishment

Source: the author, 2021.

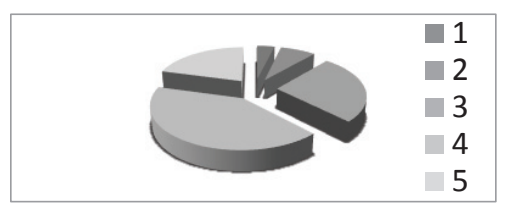

Figure 15. SDG 5 development

Source: the author, 2021.

\section{Accomplishment of SDG 6. Clean water and sanitation}

This issue is regulated by Spanish Royal Legislative Decree 1/2001 of July 20, which approves the Water Act, complemented by the hydrological plans of the existing basins in Spain, and in relation to article 25.2. c) of the 7/1985 Act of April 2, regulating the basis of the local regime, from which it turns out that it is a local public service. Its regulations set a specific legal regime with the purpose of being a sustainable public service from an economic point of view (Fernandez, 2016: 442). The establishment of supply infrastructures is connected with urban regulation, because Spanish Royal Legislative Decree 7/2015 of October 30 approves the Land and Urban Rehabilitation Act, which refers to the provision of infrastructures for water supply as a condition (among others) for the classification of land as urban. All this is completed with other regulations, such as Royal Decree-Law 11/1995 of December 28, which establishes the regulations applicable to the treatment of urban wastewater, transposing European Directive 91/271/EEC. In relation to SDG 6, the majority of people surveyed consider that compliance is medium-high, as is shown in Figure 16, since $92.31 \%$ of them rated the existence of regulation between grades 3 and 5. Consequently, the degree of compliance with this SDG in Spain is also to a medium-high degree, since $80.77 \%$ of the control group placed the level of compliance between 3 and 5 (Figure 17). More measures could be taken, but in moderate terms, since only $48.08 \%$ of those surveyed selected points 4 and 5, pointing out medium possibilities for further development (Figure 18). 


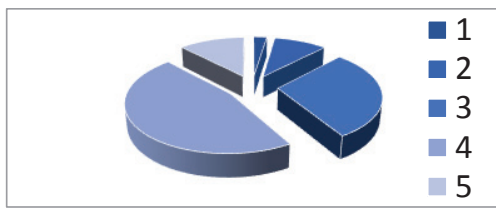

Figure 16. SDG 6 regulation

Source: the author, 2021.

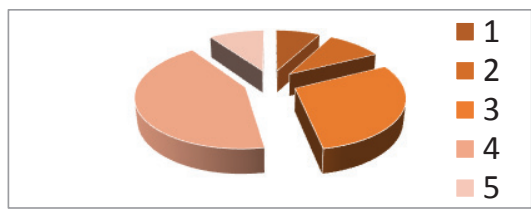

Figure 17. SDG 6 accomplishment

Source: the author, 2021.

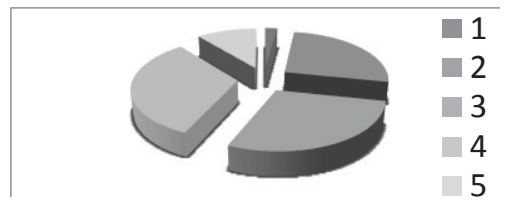

Figure 18. SDG 6 development

Source: the author, 2021.

\section{Accomplishment of SDG 7. Affordable and clean energy}

The essence of the regulation on affordable and non-polluting energy is contained in Royal Decree-Law 15/2018 of October 5, which includes urgent measures for energy transition and consumer protection, and in Royal Decree 244/2019, by which the administrative, technical and economic conditions for consumption of electrical energy are regulated. This SDG is closely related to SDG 13 about climate action, since climate change is a consequence, above all, of uncontrolled carbon emissions (Ruiz de Elvira Serra, 2016: 35). In the year 2020, progress was made in Spain towards its achievement through the declaration of the climate emergency and the approval of the Draft of the Act on Climate Change and Energy Transition of 26 May 2020. In relation to this SDG, the normative development is medium grade, since levels 3 and 4 were selected by $69.23 \%$ of the control group (Figure 19). The level of compliance is also intermediate, as is shown in Figure 20, where 3 and 4 points were selected by $76.92 \%$ of the people surveyed. But, as is shown in Figure 21, the possibilities for adopting more regulatory measures are still high, since $59.61 \%$ placed this possibility at 4 and 5 .

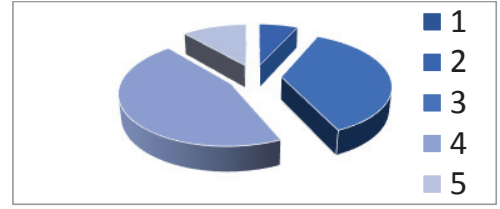

Figure 19. SDG 7 regulation

Source: the author, 2021.

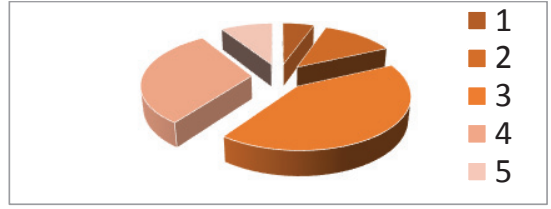

Figure 20. SDG 7 accomplishment

Source: the author, 2021.

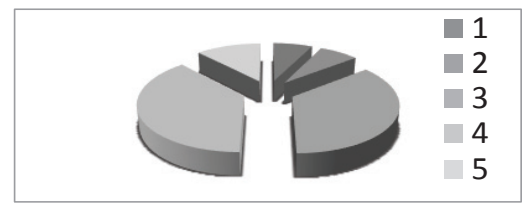

Figure 21. SDG 7 development

Source: the author, 2021.

\section{Accomplishment of SDG 8. Decent work and economic growth}

The case law C-152/11 of the Court of Justice of the European Union, of 6 December 2012 resolved a preliminary ruling question that had arisen on the application of Council Directive 2000/78/EC of 27 November 2000 on the establishment of a general framework for equal treatment in employment and occupation. The relevance of a good work environment to achieve this SDG has been highlighted, but it is not yet contemplated by law (Rodríguez Artola, 2020: 80). The extension of Spanish regulation regarding SDG 8 is situated, according to the control group, in a moderately average position, since $78.85 \%$ selected 3 and 4 points (Figure 22). The degree of compliance with this SDG is in a medium-low range, since the majority of the $86.54 \%$ of surveyed people selected 2 and 3 points, as is shown in Figure 23. The possibilities for future development are still high, according to $69.23 \%$ of those surveyed who selected 4 and 5 points (Figure 24).

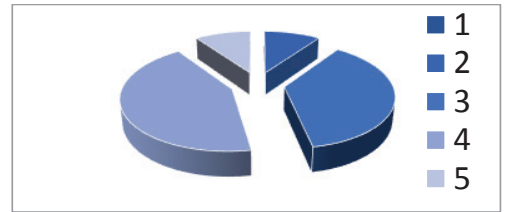

Figure 22. SDG 8 regulation

Source: the author, 2021.

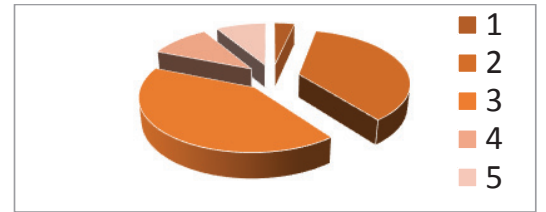

Figure 23. SDG 8 accomplishment

Source: the author, 2021.

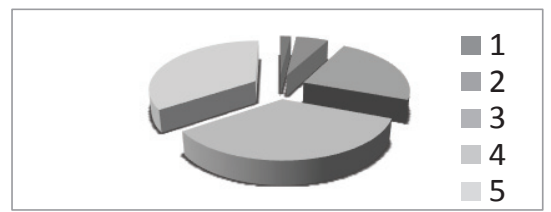

Figure 24. SDG 8 development

Source: the author, 2021. 


\section{Accomplishment of SDG 9. Industry, innovation and infrastructure}

The essential actions to improve the achievement of this SDG in Spain are contained in the Innovation Plan for Transport and Infrastructure 2017-2020, the Agenda for the Strengthening of the Industrial Sector in Spain of 2014, the State Plan for Scientific and Technical Research and Innovation corresponding to the period 2017 to 2020, and the National 5G Plan 2018-20. All of them imply large public investment to improve infrastructures and innovation. There is a relevant connection between this SDG and SDG 11 (sustainable cities and communities), in order to promote innovation to generate smart cities and territories (García García, Caravaca Barroso, 2009: 23-45; Rico, 2018: 16-17; García Álvarez, 2012: 323-332; Gomez Jimenez, 2019). The normative development of this SDG is medium-high, since $80.77 \%$ of surveyed people selected grades 3 and 4 (Figure 25), giving rise to a degree of medium-moderate compliance, according to $71.15 \%$ of the control group (Figure 26). Consequently, the possibilities for future regulatory development are still high, since 3, 4 and 5 points are given by a total of $76.92 \%$ of those surveyed (Figure 27).

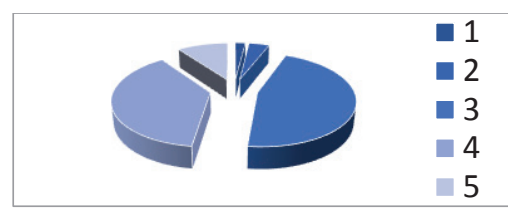

Figure 25. SDG 9 regulation

Source: the author, 2021.

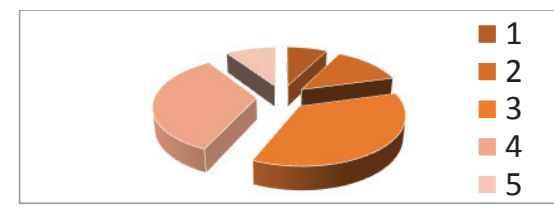

Figure 26. SDG 9 regulation

Source: the author, 2021.

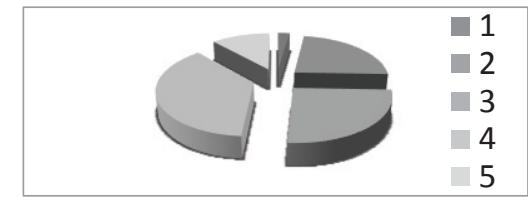

Figure 27. SDG 9 regulation

Source: the author, 2021.

\section{Accomplishment of SDG 10. Reduced inequalities}

The 20/2013 Act of December 9 on the guarantee of market unity and the 2018-2021 Immigration Plan of the Community of Madrid are evidence of the fight against inequality in different areas. This SDG is related to SDG 1 and SDG 5, in respect of economic inequality and gender respectively, so that progress in the latter ones favours the fulfilment of SDG 10 too.

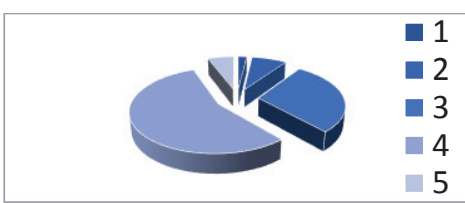

Figure 28. SDG 10 regulation

Source: the author, 2021.

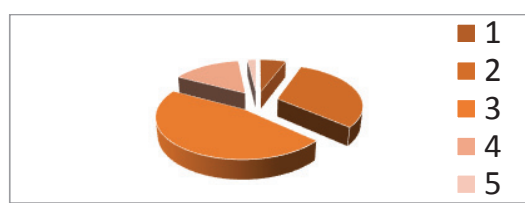

Figure 29. SDG 10 accomplishment

Source: the author, 2021.

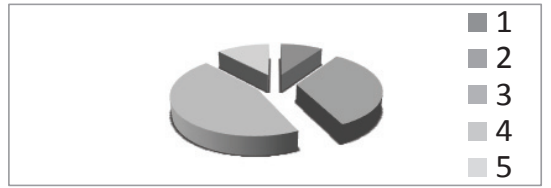

Figure 30. SDG 10 development

Source: the author, 2021.

The existence of administrative regulation is, according to $90.38 \%$ of surveyed people, medium-high, since this percentage is the result of adding the percentages of those who selected grades 3, 4 and 5 (Figure 28). However, there is a lack of regulatory effectiveness in this area, because $82.69 \%$ of the control group selected 1, 2 or 3 degrees (Figure 29). The possibilities for combating inequality through further Spanish administrative regulations is very high, as is shown in Figure 30, because $63.46 \%$ of those surveyed consider that the possibility for introducing new measures is very high (between 4 and 5 points).

\section{Accomplishment of SDG 11. Sustainable cities and communities}

Urban Spanish regulations show a preference for the model of urbanisation of compact cities (Amenós, 2015: 1-167). So we find the Land and Urban Rehabilitation of Royal Legislative Decree 7/2015 of October 30 , and regional regulation such as the 5/2014 Act of Territory Ordination, Urbanism and Landscape of the 
Valencian Community, aligned with this patron, that favours the digitalisation of territories, and makes cities and communities more sustainable and efficient. This SDG is related to others such as SDG 9, SDG 13, SDG 14 and SDG 15. The majority of the control group consider that, regarding this SGD, there is a high degree of specific regulation in force, selecting between 3 and 5 points (Figure 31). But $63.46 \%$ of the surveyed people understand that the degree of compliance is mostly low, selecting grades 2 and 3 , which should make us reflect on the adequacy of the regulatory technique of this area (Figure 32). Figure 33 shows that the possibilities for future development are high, because $82.69 \%$ of the group rated this question at 3 to 5 points.

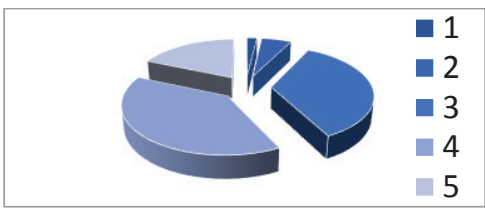

Figure 31. SDG 11 regulation

Source: the author, 2021.

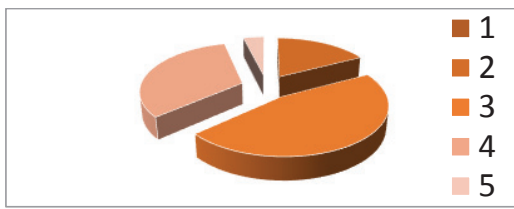

Figure 32. SDG 11 accomplishment

Source: the author, 2021.

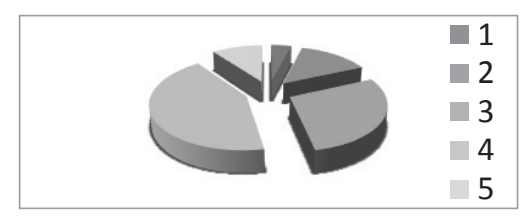

Figure 33. SDG 11 development

Source: the author, 2021.

\section{Accomplishment of SDG 12. Responsible consumption and production}

There is a huge concern in the European Union in relation to sustainable growth versus the scarcity of natural resources, and the basic lines of European regulations highlight the importance of ecological public procurement. In Spain, the Presidential Order PCI/86/2019 of January 31 publishes the Agreement of the Council of Ministers of 7 December 2018, which approves the Ecological Public Procurement Plan of the General State Administration. On a practical level, the results of recycling through consumption in some countries of the European Union should be highlighted, for example, the German Pfand plan, which allows $99 \%$ of packaging to be recycled. The promotion of responsible consumption undoubtedly affects responsible production in all sectors, including the financial sector, where irresponsible demand and the granting of mortgage loans is directly linked to the global subprime mortgage economic crisis of 2008. This leads to sector supervisors carrying out action to promote a so-called 'financial culture' (Lara Ortiz, 2017: 187-204).

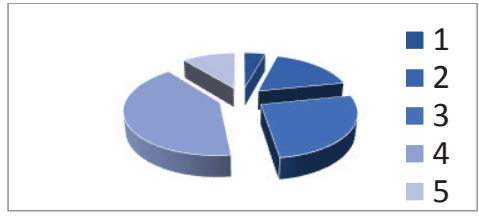

Figure 34. SDG 12 regulation

Source: the author, 2021.

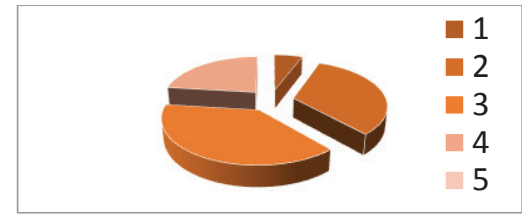

Figure 35. SDG 12 accomplishment

Source: the author, 2021.

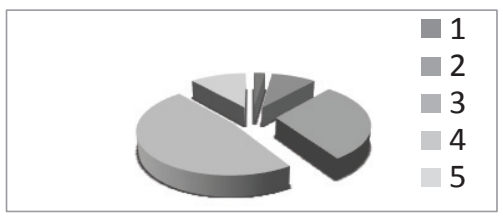

Figure 36. SDG 12 development

Source: the author, 2021.

A total of $80.77 \%$ of those surveyed placed current normative development at a medium-high degree, choosing 3 to 5 points (Figure 34). Figure 35 shows that $71.15 \%$ of the control group attributes a low level of compliance with this SDG, since this percentage represents 2 or 3 degrees (Figure 35). The possibilities for future development are very high, as is shown in Figure 36.

\section{Accomplishment of SDG 13. Climate action}

Royal Decree 18/2019 of January 25 develops aspects related to the application of the greenhouse gas emission rights trading regime in the period 2021 to 2030; and the National Integrated Energy and Climate Plan (PNIEC) for the period 2021 to 2030, promoted by the Ministry of Ecological Transition, seeks to 'transform the economic and energy model' of Spain to meet the reduction objectives of carbon emissions. The year 2020 was a turning point in this issue, since the Energy Transition Bill of May 2020 is awaiting 
approval in the Congress of Deputies. In Spain, there are some regulations that, considering the results of the survey, we can grade at between 2 and 5 (Figure 37). However, Figure 38 is very clear in showing that, after studying the current regulations, the majority of the control group consider that full compliance with this SDG is still a long way off, since grades 1 to 3 receive the highest number of votes, being a total of $84.62 \%$ of the people surveyed. Finally, Figure 39 shows that $96.15 \%$ of the control group consider that there is a lot to do (3 to 5 points).

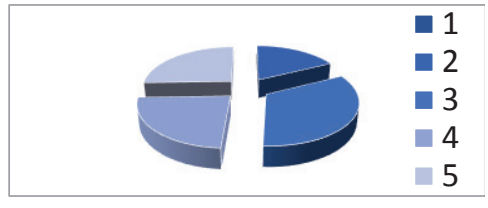

Figure 37. SDG 13 regulation

Source: the author, 2021.

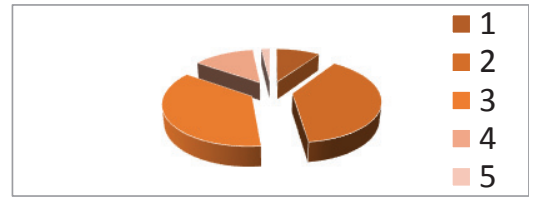

Figure 38. SDG 13 accomplishment

Source: the author, 2021.

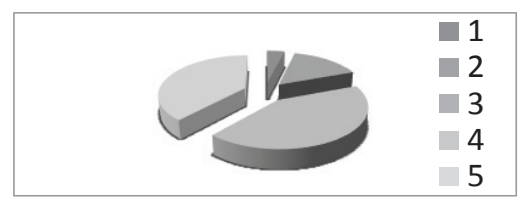

Figure 39. SDG 13 development

Source: the author, 2021.

\section{Accomplishment of SDG 14. Life below water}

This SDG is promoted by Directive 2008/56/EC of the European Parliament and of the Council of 17 June 2008, which establishes a framework for community action in the field of marine environmental policy (Marine Strategy Framework Directive), and consequently in Spain, the 41/2010 Act of December 29 on the protection of the marine environment establishes the legal regime to achieve or maintain the good environmental status of the marine environment, both volume and biodiversity (Ortiz García, 2011: 8), through planning, conservation, protection and improvement. Furthermore, in Spain we find regional and local regulations regarding this issue, because there are 5,849 kilometres of coastline (INE, 1985: 1).

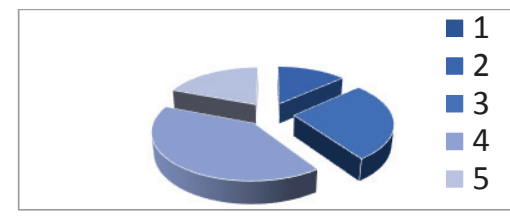

Figure 40. SDG 14 regulation

Source: the author, 2021.

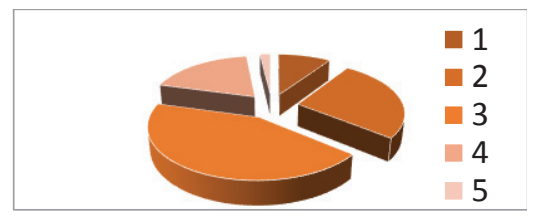

Figure 41. SDG 14 accomplishment

Source: the author, 2021.

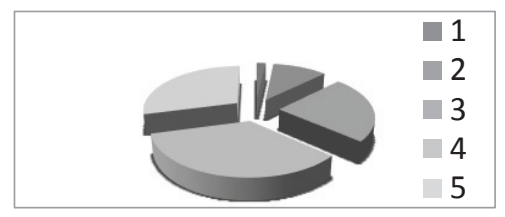

Figure 42. SDG 14 development

Source: the author, 2021.

According to Figure 40, the existence of current regulation in favour of SDG 14 is at a medium-high degree, since $67.31 \%$ value it at between 3 and 4 degrees. However, Figure 41 shows that the degree of compliance with this SDG is low, since the lowest grades (from 1 to 3 ) were selected by $90.38 \%$ of the control group. Concurrently with this, $67.31 \%$ of surveyed people rated at between 4 and 5 points the possibility of adopting more measures to achieve full compliance with this SDG in Spain (Figure 42).

\section{Accomplishment of SDG 15. Life on land}

This SDG has been the subject of interesting studies by specialised doctrine (Lopéz Ramón, 2019: $1-195)$. From the regulatory point of view, we must highlight the regulation contained in the $21 / 2013$ Act of December 9 on environmental evaluation, with a special emphasis on the contestability of administrative resolutions relating to the submission of a project or plan for environmental assessment, and the 42/2007 Act of December 13 on Natural Heritage and Biodiversity, which regulates the establishment and management of the Natura 2000 Network in Spain. This regulation is based on Royal Decree 1997/1995 of December 7, which establishes measures to help guarantee biodiversity through the conservation of natural habitats and wild flora and fauna, and the 30/2014 Act of December 3 on National Parks. All these regulations are 
complemented by the 26/2007 Act of October 23 on Environmental Responsibility, and a great number of administrative plans and programmes to promote protection of the environment. Also, there is remarkable case law about penal punishments or administrative sanctions when protected species are damaged by hunting. SDG 15 has a high degree of regulatory development in the administrative field, according to $67.31 \%$ of the control group that assessed the existence of specific standards with 4 to 5 points (Figure 43); however, the degree of compliance does not meet legal standards, according to $84.62 \%$ of the people surveyed, as is shown by Figure 44. Finally, $61.54 \%$ of those surveyed consider that regulation in this area can be enriched by more measures to a high degree, since they selected 4 and 5 points (Figure 45).

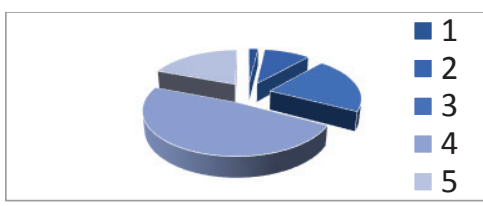

Figure 43. SDG 15 regulation

Source: the author, 2021.

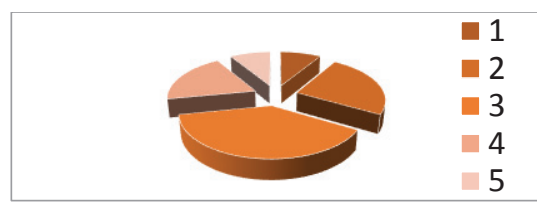

Figure 44. SDG 15 accomplishment

Source: the author, 2021.

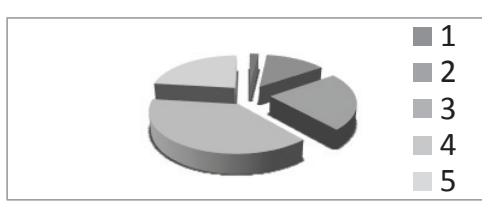

Figure 45. SDG 15 development

Source: the author, 2021.

\section{Accomplishment of SDG 16. Peace, justice and strong institutions}

The fundamental nature of the right of access to justice recognised in article 24 of the Spanish Constitution and in article 47 of the Charter of Fundamental Rights of the European Union of 12 December 2007 is the core of this SDG, and it could be improved by its modernisation, rationalisation, streamlining of procedures, reinforcing judicial independence, etc. In the same way, the achievement of the goal of solid institutions should be related to administrative transparency, citizen participation and good governance, which have undergone remarkable development in the first decades of the 21 st century, and they really imply a democratic evolution towards a status in which the citizen can control administrative activity (Tomás Mallén, 2004; García Macho, 2010; García Macho, 2014; Blasco Díaz, 2010; Blasco Díaz, 2014; Oller Rubert, 2010). The existing regulation in relation to this SDG is valued as profuse, according to $78.85 \%$ of the control group, who score the stage of its regulation at 4 to 5 points (Figure 46). The degree of compliance is medium-high, since $78.85 \%$ also rate it at 3 or 4 degrees (Figure 47 ). The possibility of adopting more measures is high, as is shown in Figure 48, because $76.92 \%$ of people surveyed give this possibility between 3 and 5 points.

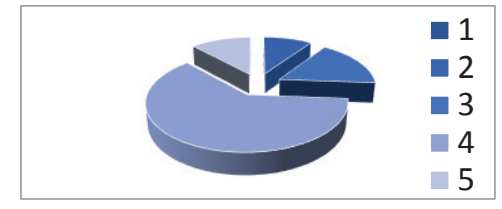

Figure 46. SDG 16 regulation

Source: the author, 2021.

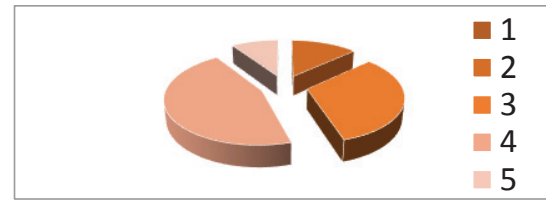

Figure 47. SDG 16 accomplishment

Source: the author, 2021.

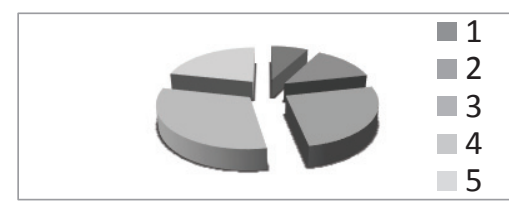

Figure 48. SDG 16 development

Source: the author, 2021.

\section{Accomplishment of SDG 17. Partnerships for the goals}

We find a specific Spanish law to generate international alliances through treaties, such as the $25 / 2014$ Act of November 27 on Treaties and other International Agreements. However, there are other possibilities that fit the strict administrative scope, such as agreements between administrations or with other public or private entities, the creation of consortia (Sanchez Morón, 2020: 423), and other forms of public collaboration, through cooperation, public contracting or other mechanisms of scientific transfer between companies and public research centres, which are supported through state and regional innovation plans (Flor Peris, Blasco Díaz, Lara Ortiz, 2020: 52-80). Considering the former mechanisms, $73.08 \%$ of the people surveyed 
consider that there is a medium normative development of this issue, as they value it at 3 or 4 (Figure 49). The degree of compliance is intermediate too, as is shown in Figure 50. Finally, Figure 51 shows that the possibilities for future normative development are considered high by the majority of the control group, since $67.31 \%$ selected grade 4 or 5 .

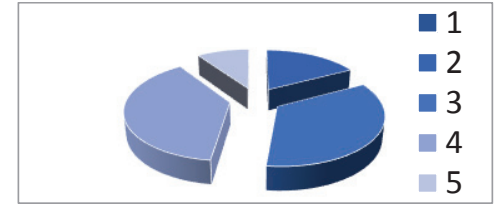

Figure 49. SDG 17 regulation

Source: the author, 2021.

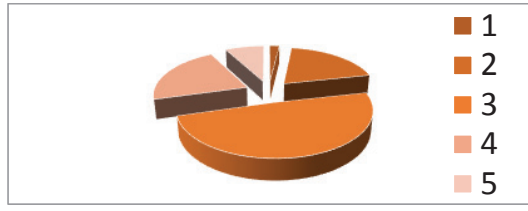

Figure 50. SDG 17 accomplishment

Source: the author, 2021.

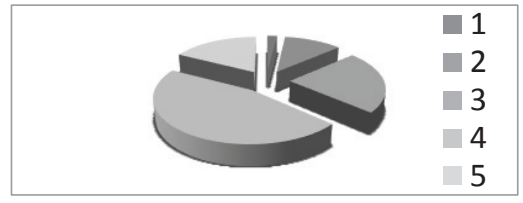

Figure 51. SDG 17 development

Source: the author, 2021.

\section{Global results overview}

The global results of the assessment show that a medium-high accomplishment has been achieved through Spanish administrative law regarding the 17 SDGs. The milestones with the highest degree of compliance are: SDG 4 (Quality education), which is the most highly achieved by regulations, followed by SDG 3 (Health and well-being), SDG 6 (Clean water and sanitation), SDG 7 (Affordable and clean energy), SDG 13 (Climate action), and SDG 17 (Partnerships to achieve goals). However, we should pay attention to the fact that there is less regulatory development in favour of other SDGs, with SDG 12 (Responsible production and consumption) and SDG 15 (Life of terrestrial ecosystems) being considered the worst, followed by SDG 1 (End of poverty), SDG 2 (Zero hunger), and SDG 14 (Life below the sea). Concurrent with these results about weaker or depressed SDGs, more promotion is possible through administrative law or informal actions carried out by public administrations through action plans or programmes.

\section{Conclusion}

This analysis reveals the extension of the accomplishment of the SDGs through Spanish administrative law, which is analysed both in a qualitative and in a quantitative sense. The results show the medium-high compliance of the SDGs considered in general terms in Spain. The study demonstrated also that the incorporation of activities that allow the transfer of knowledge about sustainability in universities produces the result of increasing awareness about the subject, and training in critical thinking to achieve a sustainable future, as a manifestation of the social responsibility that a university owes to the society in which it is. The innovative nature of the action described has allowed us not only to assess the degree of compliance with each one of the Sustainable Development Goals through Spanish administrative law, but also to provide critical thinking to the control group, and above all, what is more important, to ensure that the transfer of knowledge to future legal professionals has been done, and this will undoubtedly contribute to achieving higher levels of sustainability in the near future.

\section{References}

Amenós, J. (2015). El mito legal de la ciudad compacta. Barcelona: Bellaterra - Servei de Publicacions de la Universitat Autònoma de Barcelona, $167 \mathrm{p}$.

Andrés Segovia, B. (2020). Educación 4.0 en el Grado en Derecho. In Ferreres, Forés (dirs.). Los objetivos de desarrollo sostenible en la docencia universitaria. Su incorporación al grado en turismo. Valencia: Tirant lo Blanch, p. 171-184.

Blasco Díaz, J. L. (2010). El sentido de la transparencia administrativa y su concreción legislativa. In R. García Macho (ed.). Derecho administrativo de la información y administración transparente. Madrid: Marcial Pons, p. 121-150.

Blasco Díaz, J. L. (2014). Transparencia administrativa y cuentas públicas. In R. García Macho (ed.). Ordenación y transparencia económica en el Derecho Público y Privado. Madrid: Marcial Pons, p. 243-265. 
Brotó, O., Lapiedra, R. (2020). La inclusión de la diversidad de género en la formación para mejorar el potencial competitivo de las empresas turísticas. In Ferreres, Forés (dirs.). Los objetivos de desarrollo sostenible en la docencia universitaria. Su incorporación al grado en turismo. Valencia: Tirant lo Blanch, p. 109-220.

Coll, C., Martín, E. (2006). Vigencia del debate curricular. Aprendizajes básicos, competencias y estándares. In Actas de la II Reunión del Comité Intergubernamental del Proyecto Regional de Educación para América Latina y el Caribe (PRELAC). Santiago de Chile: Oficina Regional de Educación para América Latina y el Caribe, 21 p.

European Association for Quality Assurance in Higher Education. (2005). European standards and guidelines for internal and external quality assurance of higher education. Yerevan. $23 \mathrm{p}$.

Fernández Hernández, A. (Dir.) (2019). Compilación de la normativa valenciana desde el acceso al autogobierno: cultura, patrimonio y educación. Valencia: Tirant lo Blanch, $356 \mathrm{p}$.

Fernández, T. R. (2016). Reflexiones sobre la sostenibilidad de los servicios públicos, un nuevo principio general en gestación. Revista de Administración Pública, Núm. 200. Madrid: Centro de Estudios Políticos y Constitucionales. Available in: file://C:/Users/Usuario/Downloads/Dialnet-ReflexionesSobreLaSostenibilidadDeLosServiciosPubl-5635328.pdf [last access: April 21, 2021].

Flor Peris, M. L., Blasco Díaz, J. L., Lara Ortiz, M. L. (2020). Innovation policy instruments through the lens of open innovation. An analysis in the Spanish context. Journal of evolutionary studies in business, Vol. 5-1, p. 52-80. Barcelona: Universitat de Barcelona. Available in: https://revistes.ub.edu/index.php/JESB/article/view/j068/30818 [last access: April 21, 2021].

García Álvarez, M. (2012). Desarrollo rural, territorios inteligentes y patrimonio cultural. XII Simposio Internacional Conservación del Patrimonio de la Humanidad, Extremadura-España: Fundación Erdély, p. 323-332.

García García, A., Caravaca Barroso, I. (2009). El debate sobre los territorios inteligentes: el caso del área metropolitana de Sevilla. EURE, revista latinoamericana de estudios urbano regionales, Num. 105, p. 23-45. Pontificia Universidad Católica de Chile: Instituto de Estudios Urbanos y Territoriales.

García Macho, R. (2010). El derecho a la información, la publicidad y la transparencia en las relaciones entre la Administración, el ciudadano y el público. In R. García Macho (ed.). Derecho administrativo de la información y administración transparente. Madrid: Marcial Pons, p. 27-48.

García Macho, R. (2014). Ordenación económica transparente en el Derecho Público nacional y europeo. In R. García Macho (ed.). Ordenación y transparencia económica en el Derecho Público y Privado. Madrid: Marcial Pons, p. 11-34.

Gómez Jiménez, M. L. (2019). Retos sociales y gobernanza en las ciudades inteligentes: de los sistemas de gestión ambiental de las universidades. Campus Universitarios Inteligentes: desafios jurídicos y propuestas en el entorno urbano, p. 101-116. Barcelona: Atelier.

INE. (1985). Fondo documental del Instituto Nacional de Estadística, p. 1. Available in: https://www.ine.es/inebaseweb/ pdfDispacher.do?td=38228 [last access: April 21, 2021].

Lara Ortiz, M. L. (2017). La cultura financiera: fundamento y acciones públicas de fomento. Revista de Actualidad Jurídica Iberoamericana. Valencia: Instituto de Derecho Iberoamericano, p. 187-204. Available in: http://idibe.org/ wp-content/uploads/2017/10/AJI-n\%C2\%BA-7-4\%C2\%AA-rev.pdf [last access: April 21, 2021$].$

Lázaro Guillamón, C. et al. (2019). Administración, Estado del Bienestar, y Políticas Socioeconómicas: raíces romanísticas e instituciones de la actualidad. Col-lecció estudis jurídics, Num. 25. Castellón: Universitat Jaume I- SWPS University, $308 \mathrm{p}$.

Lopéz Ramón, F. (2019). Conservar el patrimonio natural. Madrid: Reus, 196 p.

Lucero, M. M. (2003). Entre el trabajo colaborativo y el aprendizaje colaborativo. Revista Iberoamericana de Educación, Num. Extra 33, p. 5-21. Spain: Organización de Estados Iberoamericanos (OEI).

Moreno, R., Martínez, R. J. (2006). ¿Qué podemos entender por aprendizaje autónomo? Una aproximación conductual. VIII Congreso Internacional sobre el Estudio de la Conducta. Spain: Infocop Online. Available in: http://www. infocop.es/view article.asp?id=1074 [last access: April 21, 2021].

Oller Rubert, M. (2010). El procedimiento de contratación pública como garantía de la transparència. In: R. García Macho (ed.). Derecho Administrativo de la información y administración transparente. Madrid: Marcial Pons, p. 257-282.

Ortiz García, M. (2011). La Ley de Protección del Medio Marino: hacia la gobernanza marítima. Revista Catalana de Dret Ambiental, Vol. 2, Núm 2, p. 1-31. Tarragona: Departament de Territori i Sostenibilitat de la Generalitat de Catalunya i la Universitat Rovira i Virgili. Available in: https://rua.ua.es/dspace/bitstream/10045/34956/1/2011_Ortiz_RCDA.pdf [last access: April 21, 2021].

Peña Calvo, A. (1998). Diseño de materiales para el aprendizaje autónomo de E/LE. In K. Alonso, M. Gil Bürmann (dirs.). Actas del VIII Congreso Internacional de ASELE. Alcalá de Henares: Centro Virtual Cervantes, p. 621-630.

Rico, J. (2018). Territorios rurales inteligentes: Mejor conexión digital, mejor calidad de vida. Desarrollo rural y sostenible, Num. 36. Spain: Ministerio de Agricultura, Alimentación y Medio Ambiente, p. 16-17. 
Rodríguez Artola, R. M. (2020). Marketing interno o cómo mejorar la rentabilidad de la organización a través de la satisfacción de los empleados. In Ferreres, Forés (dirs.). Los objetivos de desarrollo sostenible en la docencia universitaria. Su incorporación al Grado en Turismo. Valencia: Tirant lo Blanch, p. 73-82.

Ruiz de Elvira Serra, A. (2016). Contra el cambio climático, un cambio de mente. Ambienta: La revista del Ministerio de Medio Ambiente, Num. 114, p. 34-43 (Ejemplar dedicado a: Acuerdo de París sobre cambio climático). Madrid: Ministerio de Agricultura, Alimentación y Medio Ambiente. Available in: https://www.mapa.gob.es/ministerio/ pags/biblioteca/revistas/pdf_AM/PDF_AM_Ambienta_2016_114_34_43.pdf [last access: April 21, 2021].

Sanchez Morón, M. (2020). Dérecho Administrativo (Parte General). Märid: Tecnos, 975 p.

Sánchez Zorrilla, M. (2011). La metodología en la investigación jurídica: características peculiares y pautas generales para investigar en el derecho. Revista Telemática de Filosofía del Derecho, Num. 14, p. 317-358. Madrid: RobertoMarino Jiménez Cano. Available in: http://www.rtfd.es/numero14/11-14.pdf [last access: April 21, 2021].

The European Higher Education Area. (1999). Bolonia Declaration. Bolonia. Available in: http://www.magna-charta. org/resources/files/BOLOGNA_DECLARATION.pdf [last access: April 21, 2021].

Tomás Mallén, B. (2004). El derecho fundamental a una buena administración. Madrid: INAP, Ministerio de Administraciones Públicas, $342 \mathrm{p}$.

UNESCO. (2015). Repensar la educación. ¿Hacia un bien común mundial? Available in: http://unesdoc.unesco.org/ images/0023/002325/232555e.pdf [last access: September 24, 2020].

Ventura Franch, A. (2016). El Convenio de Estambul y los sujetos de la violencia de género. El cuestionamiento de la violencia doméstica como categoría jurídica. Revista de Derecho Político, p. 179-208. Madrid: UNED. Available in: file://C:/Users/Usuario/Downloads/17622-32884-1-SM.pdf [last access: April 21, 2021].

\title{
ISPANIJOS VYSTYMOSI DARNA ADMINISTRACINÉS TEISÉS POŽIŪRI U
}

\author{
MARÍA LidÓN LARA ORTIZ \\ Jaume I universitetas (Ispanija)
}

\section{Santrauka}

Nustatyta septyniolika darnaus vystymosi tikslų, kuriuos Jungtinès Tautos ekonominiu, socialiniu ir aplinkos požiūriu laiko visuotiniais, transformuojančiais ir ịtraukiais, taigi pagrindiniais žmonijos vystymosi iššūkiais. Norint juos igyvendinti, svarbu laikytis nustatytų taisyklių, igyvendinti numatytą ị tvarumą nukreiptą administracinę politiką. Norint ịgyvendinti darnaus vystymosi tikslus, reikia siekti, kad visų kartu žmonès suvoktų jų svarbą. Taigi svarbu šviesti jaunają kartą, kuri turètų suprasti praeities paveldo išsaugojimo ir tęstinumo būtinybę, juk nuo kiekvienos kartos priklauso būsimų kartų gyvenimas.

Tyrimo tikslas yra dvejopas: visu pirma supažindinsime su situacija Ispanijoje, igyvendinant darnaus vystymosi tikslus, antra, atskleisime, kaip svarbu puoselèti tvarumo kultūrą. Siekiant šių tikslų Jungtinès Tautos pripažįsta esminị švietimo vaidmenị: „Švietimas pats negali išspręsti esamų vystymosi problemų, bet humanistinè ir holistinè švietimo vizija gali ir turètų prisidèti prie naujo vystymosi modelio kūrimo. Taikant ši modelị ekonomikos augimas turètų būti reguliuojamas reiškiant pagarbą aplinkai, rūpinantis taika, siekiant itraukties ir socialinio teisingumo" (UNESCO, 2015: 10).

Tad universitetų ir apskritai aukštojo mokslo centrų vaidmuo svarbus ugdant tvaraus vystymosi dvasią, nes gali perduoti tvarias vertybes, kurios prisideda prie universitetų prisiimtų socialinių įsipareigojimų vykdymo. Administracinè teisė glaudžiai susijusi beveik su visais darnaus vystymosi tikslais, nes kontrolinis viešojo administravimo vaidmuo gali sumažinti žalingą organizacijų bei žmonių veiklą (taikydami adminis- 
tracines bausmes, reglamentuodami tam tikras veiklas), be to, naudinga skatinti naujus tvaraus vystymosi būdus. Pagrindinè mūsų remiama hipotezè - teorinių administracinès teisès žinių pritaikomumas, formuojant tvarumo supratimą, kaip papildomą vertę, kuri galètų būti lemiama siekiant darnaus vystymosi tikslų.

Taigi šis tyrimas apima dvi dimensijas: pirmoji - kiekvieno darnaus vystymosi tikslų igyvendinimo etapo įvertinimas, antroji - administracinis įstatymo, kaip drausmès priemonès, skirtos skleisti tvarumo žinias.

PAGRINDINIAI ŽODŽIAI: darnus vystymasis, administracinè teise, regionai, viešasis administravimas.

JEL KLASIFIKACIJA: K23, I38, I23, I25.

Received: 2021-03-06

Revised: 2021-04-28

Accepted: 2021-05-04 